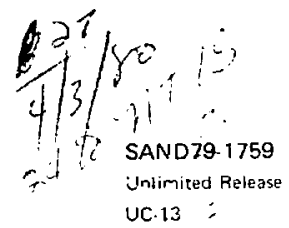

\title{
Survey of Indian Issues in the State of New Mexico Relating to Uranium Mining and Milling
}

\section{MASTER}

Sharla G. Vandevender, Sandia Laboratories

Lisa Barsumian, Shannon H. Gurbaxani, University of New Mexico

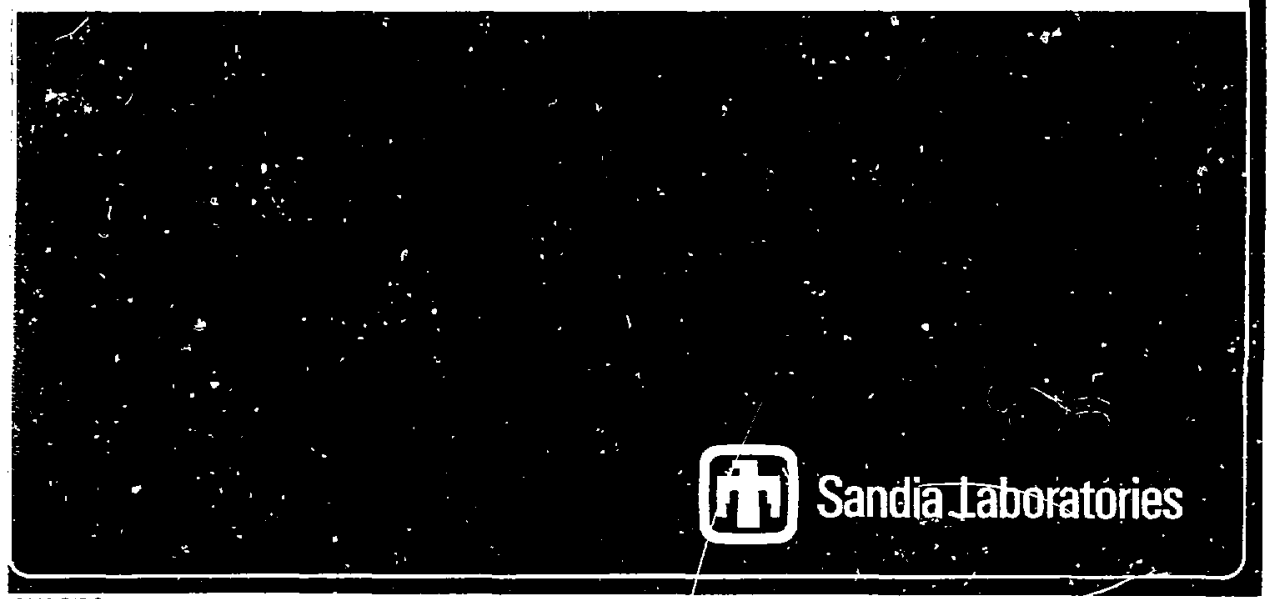


SAND 78-1759

November, 1979

\begin{abstract}
SURVEY OF INDIAN ISSUES IN THE STATE OF NEW MEXICO
RELATING TO URANIUM MINING AND MILLING
\end{abstract}

\author{
by \\ Sharla $G$. Vandevende $t^{2}$ \\ Environmental Research Division \\ Sandia Laboratories \\ Al buạue rque, NM 87185 \\ and \\ Lisa Barsumian, Shannon H. Gurbaxani • \\ Enviromental Policy Analysis Support Program \\ un iversity of New Mexico \\ Albuquerque, NM 87131 \\ Prepared for the \\ of: ice of Technology Impacts \\ Policy Analysis Division \\ Department of Energy \\ Program Managers: M. Schloss, E. P. Rrug
}

\title{
ABSTRACT
}

Estimates of ?ndian uranium resources range fron 11 to 508 of the U. S. total resources. About 17 t of New Mexico's reserves are known to be on Indian lands. New Mexico has produced almost half of the nation's uranium supply; over half of the known reserves are located within the state. However, the state has virtually no jurisoiction over development of Indian uranium. As a result, economic and environmental impacts on the state are heyond its control. The lack of state and federal control over these impacts is influencing how the Indians allow development. to proceed. The impacts of Indian uranium development also influence state control of non-Indian reserves. To the extent thit these controls af fect the availability of uranium concentrate, DOE needs to understand the issues involved. This issue peper identifies some of the related problems for both the Indians and the state and explores the reasons behind them.

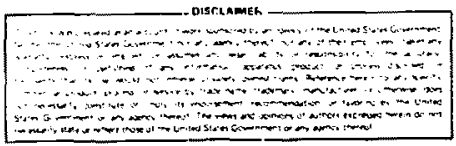




\section{EXECUTLVE SUMMARY}

Increased production of the Inited states' energy resources is creating many political issues. One of these is the effect of the development of Indian energy resources on tribal rovements toward greater poitical and economic selfdetermination. Tribal efforts to gain full control of tise development of the resources in their possession and of the benefits derived from development activities are resulting in conflicts with the state and the industry which may delay the froduction of uranium in New Mexico.

The relationship between the U. S. Government and Indian tribes has evolved through a number of stages. The Federal Government is currently the trustee to the Indian tribes. This arcangement removes the external powers of a tribal government. However, tribal governments still retain the powcrs of internal self-government. Current tribal efforts are toward fully exercising this power. Tribal governments possess legal powers similar to those of state and local governments and are the fourth government element in the United states federal system. In testing these powers, some tribes have gone to court to renegotiate terms and benefits of mineral lease sales, as well as to assert their authority to levy taxes.

states do not have legal prerogatives to intervene in Indian activities or Indian-federal interactions. Litigation concerning state jurisaiction over Indian lands has provided a clear body of case law denying independent authority to 
the states. Nonetheless, states can be affected by activities on Indian land.

Current and projected increases in New Mexico uranium development present this potential. New Mexico historically produced 468 of the nation's uranium and currently possesses 528 cf its $\$ 50 / 1 b$ reserves. Indian uranium is a prime development target in the state. Assertion of tribal control over development activity could af fect New Mexico's economy and enviconment, as well as the traditional role of uranium production in the state. Indian uranium is important to New Mexico for three reasons:

- Indian uranium comprises almost one-third of the state's oroduction and at least one-sixth of the reserves.

- As much as $30 \%$ of New Mexico's uranium revenue is derived from Indian uranium.

- Indian lands and the impacts of uranium production on them are not under state jurisdiction.

The Javajo $T r i b e$ is taking the lead in asserting Indian sovereignty. The tribe has enacted a possessory interest tax on leases and a business activity tax. Both taxes are intended to regulate energy development and increase tribal revenue. (A rezently adopted sulfur emissions regulation shows the intent of the tribe to protect its environment; the associated penalty fee will also provide additional revenue.) Although New Mexico tribes have not challenged the state's energy-mineral severance taxes, the crow Tribe's challenge to the Montana tax is being watched with interest. 
Tribal lands in New Mexico which are leased for uranium activities exceed 700,000 acres. Some Navajos have joired with an environmental group in an attempt to have the courts force a halt to further uranium development in New Mexico and in wyoring. The suit demands that nationel, regional and local environmental impact statements be written for all uranium development. If the Indians win, cessation of riew uranium development activity would deal a severe economic blow to northwester $\Omega$ New Mexico.

The state has virtually no authority to control the impacts resulting from uranium development on lndian lands. Itowever, because of the pattern of land ownership in the region, these activities also impact non-Indians. Similarly, none of the uranium mills is situated on Indian land, but most are adjacent to or surrounded by Indian land. This situation has made it difficult Eor either the state or the: tribal government to control or mitigate the impacts of uranium mining and miliing.

This issue paper presents an overview of uranium production issues in New Mexico. It is very important for the U.S. Department of Energy to understand the problems associated with Indian uranium development. However, a comprehensive review and analysis of current Iitigation related to Indian self-government is beyond the scope of this paper. Such an analysis is nonetheless necessary for a complete grasp of the issues. The cases considered should include those related to Indian sovereignty, resource use and control, taxation powers, 


\section{$-i v-$}

and authority to regulate the environment. In addition, the DOE should maintain continued awareness of Indian initiativ: 3 in these areas. 


\section{CONTENTS}

PAGE

EXECUT IVE SUMMARY

I. INTRODUCTION

II. DEVELOPMENT OF INDIAN ENERGY RESOURCES THE ISSUE AREA

Background 3

New Mexico and Indian Uranium 7

II . THE I NSTITUTIONAL SETITING

Feòeral 10

Tribal 15

State $\quad 22$

IV. SOURCES OF PROBLEMS IN NEW MEXICO

Industry Activity on Indian Land 26

Impacts of Tribal Initiatives 34

V. CONCLUSIONS 40

APPENDIX - The DOI San Juan Basin Uranium Study 41

REFERENCES $\quad 43$ 


\section{INTRODUCTION}

American Indians have observed and participated in the development of uranium in the United states from the industry's beginning. Some of the first mines were located on the Navajo Reservation in the Shiprock area of northwestern New Mexico and in the adjacent arez of Aizona. Kerr-McGee opened a uranium mill in shiprock in 1954, and leased most of the Navajo mines through the Bureau of Indian Affairs. Those mines and the mill operated until 1968, when they were abandoned. The tailings pile is located on Navajo tribal lands. Anaconda discovered the Laguna Pueblo deposits, and developed the open-pit Jackpile Mine, the ration's largest producing mine. Potential uranium reserves are reported on the reservacions of the Jemez, Acoma, Nambe, pojoaque, zuni, San Felipe, Santo Domingo, and zia Indians in New Mexico, and the Hopi in Arizona. Exxon has leased dcreage on the wind River Reservation in wyoming, and development is underway on the spokane and Colville reservations in washington. ERDA estimated in 1974 that Indian urarium provided 98 of the world's supply. 1 The Department of Energy estimates that 118 of all U. S. $\$ 30 / 1 \mathrm{~b}$ uraniun reserves are on Indian lands. About three-fourths of this Indian uranium is in New Mexico. As a result of these facts, New Mexico's Indians are beginning to recognize the importance of their resources both to themseives and to the nation.

Recent Indian assertiveness is motivated in part by the desire for sovereignty, but also by desires to protect the 
environment, control the use of resources, improve reservation communities, increase Indian employment, and increase tribal revenues, Furthermore, the tribes are endeavoring to preserve their unioue cultural values. Indian trites are employing several instituticnal tools to achieve their goals: rejecting some industrial sites, imposing taxes, renegotiating mineral leases, withholding right-of-way permits, and obtaining class I air quality designations. The Navajo, Crow, and Northern Cheyenne have gone to court for higher royalties in theit coal leases. The Council of Energy Resource Tribes (CERT) was created to help the tribes obtain more favorable new mineral leases, to help renegotiate poor leases, and to determine what resources the tribes own. The Navajo are also now using right-of-way permits as Teverage to renegotiate coal leases.

potentially overlapping levels of governmental regulation of land, air and water on tribal lands make industry hesitant to locate facilities there. This paper discusses some of the major sources of conflict in New Mexico. 
I I. DEVELOPMENT OF INDIAN ENERGY RESOURCES - THE ISSUE AREA

The growth of issues related to Indian energy resource development has arisen out of national energy needs and a concurrent tribal movement toward political and economic selfdetermination. The primary parties acting in this policy arena are the federal government and the several tribes holding major energy resources. However, states with resource-iich Indian land within their boundaries will be affected by the actions taken by these parties.

\section{BACKGROUND}

The root of the issues surtoinding Indian energy resource development is the unigue status of Indians and their lands. The relationship between Indian tribes and the united states Government has evolved through several different stages. Currently, the federal government has a legal trust responsibility for the Indians. This trust responsibility is affirmed in a series of court decisions and congressional acts. The most notable of these are the Indian Reorganization Act of 1934,25 U.S.C., 461-79; Cherokee Nation v. Georgia, 10 U.S. (5 Pet.) 1 (1331); and Seminole Nation y. The United States, 316 v. S. 286 (1942). As a result, Indian lands and the mineral resources existing on them are held in trust by the federal government for the Indians. This trustee role is administered through the Bureau of Indian Affairs under the direction of the secretary of the Interior. 
"Many of the problems and issues likely to arise when Indian-owned resources are developed will resuit primarily from the former status of Indian tribes as sovereign nations. When these tribes were incorporated into the U. S., their external powers were terminated and they were made subject to the legislative power of the U.S. However, except as modified by treaty or the express provisions of federal government, the tribes still possess the fowers of local self-government."

Among the Indian tribes, dissatisfaction has been growing over the exercise of this federal trust responsibility. Increasing political sophistication and the desire for greater economic self-determination is causing tribes to react against the federal. trustee role which they feel has grown to include management of most Indian activities. From the tribal standpoint, this expansion infringes upon the ir rights of local selfgovernment. Tribes are now seeking to gain control of the many decision-making powers currently exercised by the federal government through the Pureau of Indian Affairs, its Commissioner aw the secretary of the Interior. The issue of tribal sovereignty is the subject of a continuing debate between the trikes. Indian interest groups and the Federal Government.

The hardling of mineral leasing on Indian lands by the Department of Interior is a primary point of contention in the self-determination drive. The Omnibus Mineral Leasing Act of 1934 (52 stat. 347, 25 U.S.C.A ss 396a, et.seg. 1963) "authorizes the leasing of unalloted or tribal and ceded lands for mining purposes. Under this Act, the tribal council or other authorized spokesman for the tribe may, with the approval of the Secretary of the Interior, enter into a lease not to exceed 10 years 'and so long thereafter as minerals are produced in 
peying quantities." 2 The Indian Department Appropriations Ast of 1909 (35 stat. $78 j, 25$ U.S.C.A., 396 (1963), and its implementing regulations in Title 25, Code of Federal Regulations, Part 171, authurizes the mineral leasinn of al lotted lands under similar procedures and regulations. 3

The prevalent Indian viewpoint now is that tribal approval of past leases was given without clear understanding of the rypes of agreements into which the tribes were entering. "Leased and lost" is a phrase reflecting Indian sentiment over tribal benefits from past mineral leasing. Although the Bureau of Indian Affairs has been reguired to have tribal approval before a lease sale could be authorized by the secretary of the Interior, in the past tribes did rot uncertake an independent examination of lease terms. They relied ıpon BIA evaluations instead. This lack of independent examination, poor knowledge

: tribal mineral reserves, and lack of tribal understanding of the economics of mineral development has been recognized as the problem with leases negotiated in the past. This void is now being filled as mineral-rich tribes are recruiting their own expertise and pressuring the federal government to inventory tribal mineral holdings pursuant to its trustee role.

Some tribes are resorting to legal proceedings to renegotiate lease terms to increase their profitability. Cases in point are the successful Navajo fight to renegotiate an Arizona coal lease with El Paso Natural Gas and Consolidation Coal, Northern Cheyenne actions to renegotiate two coal 
leases on their land in Southern Montana, and a class action suit brought by the Jicarilla Apaches against the Secretary of the Interior and a number or lessees in attempt to cancel $100 \mathrm{mineral}$ leases on their land.

other arrangements besides leasing are being explored by the trjbes. The Navajo-Exxon contract is an example of a new type of arrangement. The Navajo-Exxon agreement is a joint venture in uranium exploration and development on Navajo tribal land in northwest New Mexico. This arrangement has been controversial because it was negotiated without prior approval of the Secretary of the Interior. In 1972, the Navajos dealt Jirectly with Exxon, after having utilized a competitive bidding process in which Exxon offered the most favorable terms. 4. though the Navajo method deviated from prescribed procedure. it was subsequently approved by the secretary making it valid ane binding.

This independent action reflects Navajo determination to control and fully benefit from the development of their uranium resources. The Navajo tribe has also been active in assisting other tribes to benefit from energy resource production; the Navajo Tribal Chairman is the current chairman of CERT. As the largest and most politically experienced tribe, the varajos are blazing trails which can be expected to set precedents for other energy resource tribes. The Indian tribes are now aware that careful management of nor-renewable energy resources can provide a long-term economic benefit. They are beginning to develop that management capability. 


\section{NEW MEXICO AND INDIAN URANIUM}

In response to projected national energy needs, New Mexico is experiencing a resurgence of demand for its uranium reserves. New Nexico is the leading uranium producing state and has the largest reserves. Until recently, the fact that much of these reserves were located on Indian lands did not attract special attention. However, current lease sales and explocation activities indicate that much future development activity will take place on Indian land.

Formerly, the lacation of uranium development on Indian Iand had not presented the state with difficulties. The state's position has been one of an interested, although essentially passive, party. Uranium has of Fered New Mexico an industry providing employment and zevenue at a time when incentives for other types of industrial development have been limited. Now, the poitical environment surcounding Indian uranium development is becoming more volatile. New Mexico is facing uncertainties about how it may be affected by this issue in the future. New Mexico's 104,000 Indians on 25 reservations comprise 78 of the state's population (see Tatle I). Indian history and culture are an integral part of vew Mexico's heritage. The Indian arive for tribal sovereignty and economic selfdetermination is an important issue within the state. Tribal interest groups include Americans for Indian Opportunity (AIO), National Indian Youth Council (NIYC), All Indian Pueblo Council, and New Mexicans far Tribal Development. Newspaper articles appear weekly in the Albuguerque Journal, Albuguerque Tribune, 
and Navajo Times pertaining to the changing attitudes of Now Mexico's Indian tribes toward energy resource development on their land.

Indian uranium development in New Mexico al ready includes two major projects. The Navajo-Exxon joint venture covers 400,000 acres (525 square miles) of the Navajo Reservation in san Juan county in the noithwest guadrant of the state. Also, the largest open-pit uranium mine in the world is located on Laguna Pueblo land. These are the two largest current endeavors. Other present and future Indian uranium activities are discussed in Part IV. The importance of India.r uranium to New lexico lies in two factors: (a) Indian uranium comprises a large portior. of the total reserves within New Mexico and (b) Indian lands end activities upor them fall under federal, not st, $e$, jucisaiction. The overall result of the combinatior of these two factors is that while New Mexice and the Indian tribes are separate legal entities in the federal system, Indian and state boundaries overlap and the activities of each grouf af fect the other. 
TABLE I

Indians in New Mexico

LAND AREA

URANIUM (U) \& COAL (C)

A.TIVITY

NAME

POPULATION

Present

potential

Acoma

2,700

246

$\mathrm{U}, \mathrm{C}$

Pueblo

1,000

29

U

Pueblo

2,600

211

Isleta

Pueblo

2,100

89

u

pueblo

5,100

417

Laguna

300

23

Sandia

Pueblo
San Felipe 2,300
Pueblo
Santa Ana 500
Pueblo
Santa $\quad 2,900$
Don ingo
Pueblo

48

U

45

69

U

Zia Pueblo 600

113

U

$$
\begin{aligned}
& \text { Nambe } \\
& \text { Pueblo }
\end{aligned}
$$

300

19

Picuris

200

15

Puebio

Pojoaque

puel bo

100

12

San Ilde-

fonso

Puelbo 


\section{LAND AREA}

URANIUN (U) \& COAL (C) ACTIVITY

NAME POPULATION IN THOUSAND ACRES

San Juan

Pueblo

1,700

12

Santa

Clara

Pueblo

1,200

46

Taos

Pueblo

1,500

45

Jicarilla

Apache

2,100

742

C

Mescalero

Apache

2,400

460

Zun i

Pueblo

6,300

407

Navajo

Main

Reser-

vation

Navajn

Al lot ted

Unknown

597

Ramah

ivavajo

1,600

147

U, C

A lama

Navajo

1,100

63

Canoncito

Navajo

1,300

77

Ute

Mountain

1,400

105

c 


\section{THE INSTITUTIONAL SETTING}

The institutional and jurisdictional milieu in which Indian uranium development is taking place involves a complicated responsibility structure and considerable ambiguity. Sorting through these responsibilities to achieve a clearer understanding of what agencies play which roles poses a major challenge.

\section{FEDERAL}

It is clear that the federal government currently has primary responsibility for Indian external affairs and Indian lanas. Oversight of Indian uranium development involves several federal roles. These are a) protection of Indian interests (its trustee role); b) ensuring sufficient production of $\mathrm{U}_{3} \mathrm{O}_{8}$ for nuclear power generation (national energy development mandate); c) safeguarding the nation's environment from abuse and deterioration (a responsibility created out of a substantial body of federal environmental protection law*) and d) preserving state autonomy from federai encroachment (Constitutional Law). The challenge of ensuring proper oversight is compounded by this combination of divergent, possibly conflicting roles of the U. S. Government. Table I gives a

\footnotetext{
*Including the National Environmental policy Act (NEPA) of 1969, Environmental Quality Improvement Act (1970), Clean Air Act and Amendments (1967, 1977), Energy Supply and Environmental Coordination Act (1974), Clean Waters Act (1977), Surface Mining Control and Reclamation Act (1977), Water Resousces Planning Act (1964, 1971) and the Safe Drinking Water Act (1974, 1977).
} 
partial list of federal agencies and their subdivisions involved in uranium development activites - both Indian and non-Indian.

The Bureau of Indian Affairs within the cepartment of the Interior is the liasion agency between Indian tribes, other agencies, and private development companies. Although previous proredures are now being challenged by the tribes, it has been the sractice that the approval and sale of all Indian mineral leases were undertaken by the secretary of Interior. After a lease sale is completed, exploration and development, and minirz plans and operations must be reviewed by the BIA and ather federaI agencies involved in uranium development. A single uranium development project freauently includes a number of ieases, some of which may involve both Indian and non-Indian lands. One uranium mining operation could be comprised of leases on Indian, federal, state and private lands. This increases the number of althorities whic. re involved in the approval process. 
TABLE II. Federal Agencies Overseeing Uranium Development in New Mexico

U. S. Cepartment of Interior

Park Service

Facility Engineering

Geological survey

Fish and wildife

service

Bureau of Land Management

Bureau of Indian Affairs

Bureau of Reclamation.

Indian Health Service

Land office

U. S. Publi: Health Service

U. S. Department of the Army

corps of Engineers

U. S. Department of Agriculture Forest Service

U. S. Department of Energy

U. S. Nuclear Regulatory Commission

U. S. Internal Revenus Service

U. S. Department of Labor

U. S. Securities and Exchange Commission

U. S. Department of Transportation
U. S. Equal Employment opportunities Commission

U. S. Department of Just ice

Inmigration and Naturalization service

U. S. Occupational Safety and Health Administration

U. S. Mining Enforcement and safety Administration

U. 3. Finvironmental protection Agency

4. S. Bureau of Mines 
Uranium mills are the responsibility of the U. S. Nuclear Regulatory Commission, although this responsibility is delegated to the state if the state has an "agreement status" in compliance with the 1954 Atomic Energy Act. Although New Mexico is an agreement state, the question of jurisdiction on Indian lands has not arisen because at present there are no uranium mills on Indian lands. The industry has chosen to aroid the difficulties which are associated with locating processing facilities on Indian lands.

Mill tailings supervision has been the focus of recent Congressional debase. It is now recognized that abandoned tailings piles, created during the initial uranium development period when the Atomic Energy Commission was the sole buyer, represent health and environmental hazards. Adequate management of lailings has been sought by the affected states. The federal Uranium Mill. Tailings Padiation Control Act, passed in late 2978 , Jistribuces the costs for tailings clean-up 90 ? rejera.tin; state. The federal government will pay 100 of the clean-up costs for abandoned tailings on Indian inands. While federai responsibilities have been outilined here, it should not be assumed that the oversight process proceeds smoothly. The management of uranium mining companies claim to be spending a large portion of their time dealing with various government agencies. coordination of the activities of the various agencies, bureaus and commissions would serve to reduce the administrative confusion, possible duplication of effort or gaps to which such a system is vulnerable. The 
complexity of federal resource administration does not ennance the outlook for naticnal uranium production goals. This is particularly true for Indian uranium development, an issue area inherently complicated in its political and $i \in g a l$ aspects. 6

\section{TRIBAL}

Tribal governments are responsible for internal Indian affairs. The federal government is the only other governmental level with authority to oversee or affect Indian activities. As the legal trustee for the Indians, the federal government has interpreted its cole very broadly. However, tribes are Aemanding greater jurisdictional latitude without federal participation. They are strongly asserting their legal rights to selE-government.

The Navajo Nation tribal government consists of several units. Those involved in different capacities with uranium development include the Navajo Environmental Protection Agency, the Office of Navajo Labor Relations, the Navajo Tribal Council, Navajo Tax Commission, Office of Minerals, Division of Resources, and Land Administration Department.

In response to tribal movements toward independent jurisdiction, the federal government is in the process of celinguishing some of its previous authority to the tribes. New regulations have been drafted and partially approved by the Department of the Interior. They introduce major changes responsive to some of the expressed desires of the Indians. 
These changes $I$ iminate the current emphasis on leasing and add provisions which allo: other alternatives, such as joint ventures; assign tribes the initiative in developing their resources, rith or without the sec ary's (and BIA's) assistance as the tribe desires; eliminate the requirement of Secretarial approval to enter into negotiations; and rectuire economic, environmental, and social and cultural impact assessments prior to any agreement being approved by the Secretary. However, resource development agreements will still require the Secretary's approval under the omnibus Mineral Leasing Act. 2 The effects of these changes on energy resource development and federal goals for meeting energy sufply demands is uncertain.

Navajo dissatisfaction with federal practices may result in slowing new uranium development if the government loses a case now before the federal district court in the District cf Columbia, peshlakai vs. Scchlesinger. A group of Navajo homeowners and ranchers, joined by the Friends of the Earth and the New Mexicc Navajo Ranchers Association, charge the federal government and the uranium industry with inadeguate consideration of the environmental impacts of mining. The lawsuit charges that cieliberate disregard of the environmental impacts of mining has been federal policy. It seeks an injunction against all new uranium projects in the san Juan (New Mexico) and South Powder River (Wyoming) basins until national, regional, and local environmental impact statements are completed and approved. It Eurther charges that existing 
environmental impact statements are inadequate ar.a should be redone.

The lawsuit, fijed in December 1978, must he resolved guickly to avoid the loss of leases which have imminent expiration dates and minimum-production reguirements for renewal. Intervenors in the governmert's behalf include Mobil, Conoco, Phillips rranium, Kerr-McGee, United Nuclear, Gulf and Exxon. The federal agencies named in the suit are the Defartments of Energy, Interior and Agriculture, the Environmental Protection Agency, the Nuclear Regulatory Commission and the Tennessee Valley Authority.

Power of taxation is an important aspect of economic self-government that the tribes are utilizing. The litigative process seems to be favoring the tribes in tests of this right. Two Navajo taxes are curcently urider challenge: a possessory intorest tax and a business activity tax.

Under the proposed possessory interest tax "possessory interest is the value of a lease granted by the Navajo nation." The value does not include improvements, but, rather, the value of the lease site and the value of the underlying resources such as coal, oil, gas and uranium. The Navajo rax Commission determines the value of the possessory interest. The value, which is somewhat analagous to assessed valuation in property taxes, is used as a tax base. The tax rate to be applied will lie between $1 z$ and $10 \%$. As of calendar year 1978, the tax rate proposed by the Tax commission was 38 (to be applied to the tax base). Leases yalued at less than 
$\$ 100,000$ are exempt. The business activity tax leries 75 percent rate quatterly on the gross receipts of large companies doing business on the reservation. The first $\$ 125,000$ of income or 10 percent of gross Navajo receipts (whichever is greater) is exempt.

In a case recently decided in an Arizona Federal court, U. S. District Judge william Copple ruled that the salt River Project and the City of Los Angelis can be taxed by the Navajo Tribe for their possessory interests in the lavajo generating station at Page, Arizona. 7 (The decision did exempt from tax the 24.3 per cent interest held oy the 1. s. Government.) The decision is under appeal.

Industry is clearly opposed to these taxes, which were devised primarily to provide revenue from large energy projects. In a recent public hearing of the Navajo Tax Commissic., industry representatives testified, claiming heavy taxes could drive away current business, discourage future business investment, and aggravate present economic problems. Industries represented at the meeting included: General Dynamics, Arizona Public Service Ccmpany, Exxon, Mobil Oil, Gulf Oil, Standard Oil of Indiana, Chevron, Union oil of California, Phillips Petroleum, shell oil and Getty 0 il. 8

The Four Corners Power Plant is located on the New Mexico portion of the Navajo reservation. Ownership of this plant is divided between the Public service company of New Mexico, the Arizona Public Service Company, and four other utilities. This group has filed suit in Albugueroue to prevent 
the possessory tax levy on the four Corners plant. As of May 17. 1979, a total of sixteen companies had challenged the Navajo possessory interest and business activity taxes in si: suits filed by utility companies in New Mexico and Arizona, a major uranium company in New Mexico, and oil and gas companies in utah. 9

Along with business taxes, severance taxes are attracting the interest of tribal governments. The Crow Tribe in Montana is currently seeking to preempt state severance taxes on coal development on their reservation with the tribe's own 25 percent severance tax. The tribe claims that the state fax "violates Congress' 'exclusive authority over the regulation of commerce with Indian tribes'". 10 The U. S. District court ruled that Montana may impose its 308 severance tax on Indian coal prosuced by non-Indian companies. The court said an Act of Congress would be reauired to allow non-Indian companies to share the tribe's immunity from state law. The tribe $w: 11$ appeal the ruling.

The exercising of tribal taxation powers can ditectly affect the industries and states involved and indirectly afiect the nation's energy and economic situation. From the industry standpoint, the establishment of, or increases in, tribal taxes may make their operations on Indian lands economically unattractive. Industry argues that double taxation from the tribes and the state represents too great a financial drain to warrant continuing their activities. This view was expressed at a recent pubiic hearing of the Navajo Tax Commission. 
These battles are now being fought in court. However, if Indian tribal taxation powers continue to be supported by court decisions, industry investment could be discouraged. On the other hand, tribal governments appear to be firm in asserting their taxation powers. The Navajos anticipate a \$26 million annual revenue from their two new taxes. Currently, Navajo revenues from energy development do not equal those received by the states from production or severance taxes on projects located on Navajo lands. The tribes feei that an independent financial base is the key component of self-government. Industry arguments $\because$ iainst tribal taxation structures are not finding a sympathet ic audience among tribal auえhorities.

Another area in which the Navajo tribe is assuming jurisdiction'is the control of sulfur emissions from power plants. The two largest coal-fired power plants in the nation are located on the Navajo Reservation, at Page, Arizona (Navajo Station, 2310 Mhe), and at Farmington, New Mexico (Four Corners Station, 2162 MWe). A sulfur emissions tax was enacted by the tribe, with the intent of requiring 998 sulfur removal from emissions. The tax is seen as "an econom ic incentive for the companies to install pollution control equipment." 11 The Navajo plant currently has no sulfur emission control equipment and the Four corners plant essentially has none. 12 This tax has been challenged in federal court. The challenge was dismissed in Arizona because the Secretary of the Interior had not approved the tax. A similar challenge is pending in 
the New Mexico Federal Court. In order to get Interior Department approval the tribe will have to revise the sulfur emission penalty fee and al low the companies sufficient time to instal 1 pollution controls.ll The fee in question escalates from $\$ 0.15$ per pound of sulfur discharged in 1978 to $\$ 0.75$ per pound in 1982 , with the first 250,000 pounds discharged per guarter exempted. This action demonstrates the Tribe's determination to protect its enviroment through its own environmental regu1ations.

The Navajo Land Administration Department (LAD) and the Navajo Envirormental Protection Agency can withhold approval of proposed rights-of-way and industrial sites if they find the development proposals dangerous or environmentally unsound. Rights-of-way disputes associated with haul roads and power transmission lines can significantly impede mine and mill development. In addition to the LAD approval, rights-of-way on Navajo trust land must aiso be approved by the affected people, the area BIA office, the office of Labor, and the Tribal Chairman. On Navajo fee lands, the affected people, the tribal Legal Department, the Resources Advisory Committee of the Tribal Council, as well as the Chairman must approve. These multiple approvals make right-of-way negotiations with the Navajos a lengthy process.

In January, 1979, the LAD froze the issuance of all rightof-way permits, both new and renewal. All existing permits will be reviewed. The term of each permit may be shortened to five years with no automatic renewal. The tribe is using 
right-of-way permits as leverage in forcing renegotiation of royalty rates in existing mineral leases. The tribe is also considering incteasing permit fees, reguiring stringent enforcement of Navajo hiring preference, a. reguiring environmental protection as conditions for renewal of permits.

The uncertainties involved make industry hesitant to locate on Indian land. The current litigation in the federal court in llew Mexico between the utilities and the Navajo Tribe will determine whether companies can be legally subject to tribal reservation air guality standards and penalties. It will also determine whether the tribe can enforce the possessory interst tax in the state, as well as whether resource extraction companies which pay the tax can pass the cost on to the utilities. The District Court in Arizona has held that the tribe does have authority to levy the possessory interest tax. Although the ruling has been appealed, the tax, along with the business activity tax, will be collected in 1979. other tribes are watching the Navajo's taxation efforts. The Worthern Cheyenne and the crow in Montana are planning taxation programs.

\section{STATE}

The federal system in the united states was originally conceived to be comprised of national, state and local levels. The subsequent authorization by Congress of tribal sovereignty introduced an additional element to the federal 
system that produced overlapping geographical and jurisdictional boundaries betweer tribes and states. While this was a positive policy direction for the authority relacionship between the national government and Indian tribes, it left the affected states in a potentially problematic situation. The federal-Indian relationship has evolved through a series of stagrs. Its final disposition does not yet appear to be at hand. From the state perspective, the vulnerability of their position in view of the changing political and energy situations may result in a defensive posture. State responses to future events involved in Indian energy resource development, primarily in the West, will merit monitoring. States have little or no jurisdiction over Indians and Indian land. The federal government is the only governmental entity with jurisdiction aside from the tribes themselves. There have been a number of court cases dealing with the issue of state jurisdiction versus the sovereignty of Indians and Indian land within their boundaries. 13 In these cases, the states have been unable to assert jurisoiction to any significant degree. In William v. Lee, 358 U.S. 217 (1959), the supreme Court concluded that reservations are unique legal entities over which state governments have no powers not expressly given them by congress. 2 Therefore, although Indian lands may exist within state borders, a state has no independent legal jurisdiction over those lands or the activities taking place on them. 
Tt:is solid legal basis for exclusior of Indians and their land from state jurisdiction clearly leaves the tribes and Federal Government in control. But exclusion from legal involvement does not necessarily mean exclusion from other types of irvolvement for those states containing Indian land. New Mexico has almost no formal partis pation in uranium development on Indian lands. However, through its status as an "agreement state," New Mexico does possess the authority to monitor uranium milling activites in lieu of the Nuclear Regulatory Commission. Thie Ervironmental Improvement Division is the responsible state agency. Currently, there are no uranium mills on Indian land, but should any be constructed in the future, it is not clear that the state has the authority to oversee them.

- A major area of concern surrounding uranium development activities in New Mexico is safeguarding the environment from damage. The physical environment and its natural resources do not respect politically-determined land divisions. Therefore, impacts upon terrain, vegetation, animal life, air and water originating from development activities on Indian land have the potential to affect the state's ecosystems.

Known environmental impacts from uranium mining and milling in New Mexico include:

A. Water guality

1. Surface water contamination

2. Ground water contaminatjon 
B. Water quantity

1. Reduction of water supply

a. from mine dewatering

b. from increased consumption

2. Changes in the allocation of water rights

B. Air quality

C. Radioactive emissions

D. Land use

1. Alteration of landscape

2. Land withdrawal for mill tailings and mine spoils

E. Community impacts

Since New Mexico does not have independent, cnvironmental jurisdiction on federal or Indian lands, it is reliant on the administration of federal and tribal laws and regulations to mitigate these impacts. Therefore, the manner in which these parties administer their environmental authority is of importance to the state. 


\section{SOURCES OF PROBLEMS IN NEW MEXICO}

At present, the State of New Mexico's position is that of interested observer of interactions between Indian tribes and the federal government. As the situation continues to evolve between these principal parties, New Mexico's policies can be expected to evolve as well.

\section{INDUSTRY ACTIVITY ON INDIAN LAND}

Resources occur on Indian lands throughout the uraniumEich northwest quadrant of New Mexico. Indian lands include: 1) tribal or unalloted land, 2) allotted land and 3) ceded land, 14

Tribal (unallotted) land is that which is held by the U. S. Ggvernment in trust for the entire tribe and subject to federal restrictions against alienation or encumbrance. This is the tribal reservation. Allotted land was created as a result of the General Allotment Act of 1887. This policy allotted land to individual Indians, although it was still held in trust by the U. S. Government for the benefit of that individual, subject to the same federal restrictions as tribal land. The allotment plan was not as successful as had been anticipated, which gave rise to the third category of ceded lands. Land reserved for Indian allotment but not utilized by individual Indians was then opened for settlement by nonIndians. The tribes, however, did ratain mineral rights to these lands. An additional category of Indian land involves 
federal ly-owned mineral rights under?ving Indian surface ownership. The BIA holds that surface owner (Indian) consent is reyuired before federal leases may be sold. The Interior Department's solicitors office is expected to rule on this question soon. All four Indian land categories are open to mineral leasing through the secretary wf the Interior. ${ }^{3}$ uranium accurs on all these categories of Indian land in New Mexico. The anticipated growth of the uranium industry in New Mexico in the next ten years would have great impact on Indian land. Estimates vary as to how much of the Uniter states' uranium reserves are on Indian land. A report issued by the Americans For Indian opportunity sta'es that it is impossible to say with certainty how much of the nation's energy resources are owned by Indian nations because there are no comprehensive inventories available to the tribes. 15 The teport goes on to state that actual production of uranium on Indian lands was $25 \%$ of total U. S. productior. 'n 1976 (p. 4). There are conflicting estimates of uranium resources on Indian lands. The Fxecutive Director of CERT, the Council of Energy Resources Trıbes, claims that Indians own hal of U. S. uranium resources. 16 The Grand Junction office of DOE estimates uranium reserves on Indian lands as shown in Table IIIa.

Uranium industry statistics produced by the Grand Junction office show that New Mexico has been and will remain the nation's primary producer of yellowcake. The state has supplied 468 of 2ll yellowcake produced in this country and has reserves* that *53 of $\$ 30 / 1 b$ reserves and 528 of $\$ 50 / 1 b$ reserves. 17 
indicate it will produce over half of the future supply. As can be seen in Table IIIb, a significant portion of these reserves is located on Indian lands.

TABLE IIIa. Uranium Reserves on Indian Land 17 (as of U. S. Total)

Known Probable Possible speculative

$\$ 30$ per ib

$\mathrm{U}_{3} \mathrm{O}_{8}$ forward

118

B. B8

25.58

7.78

cost

TABLE IIIb. Known Uranium Reserves on Indian Land 18 in New Mexico

of N.M.Total N.M.Z of U.S. Total

$\$ 30$ forward cost

$\$ 50$ forward cost
15

17
B

9

Despite uncertainty as to exactly how much uranium exists on Indian land, present and future industry activity is very likely to be extensive. In 1976 the Department of the Interior reported that 284,600 acres of Indian tribal and allotted lands were leased for exploration and development of uranium in Northwest New Mexico. Of these 14,300 acres were Laguna Pueblo land and the rest Navajo. 19 Added to this are 400,000 acres for the recently approved Navajo-Exxon exploration project. In addition, the DOI Report states that there are 62,000 acres under consideration for potential lease sales on the Canoncito Navajo reservation and 78,000 acres on Jemez and 
Zia Pueblo lants in which the companies are now expressing interest.

Table IV lists the present and planned developments of the uranium industry on Indian land in northwestern New Mexico. It shows that Indian lands are involved in 17 existing and planned facilities (out of 45 for which information could be obtainea). Yowever, if one included all those facilities which are adjacent to or require access over or water rights from Indian land, Table IV would be much longer. This is because much of the adjacent land to the south and east of the Navajo Reservation has a "checkerboard" Iand ownership pattern. If one examines a land status map of the area, it resembles a large checkerboard with various one-mile squares assigned as follows:

1. Navajo allotted lands, i.e., lands owned by individual Yjavajos as opposed to lands held by the tribe in common.

2. Federal lands

a. Public lanas under the jurisdiction of the Bureau of Land Management,

b. National forests, Department of Agriculture,

c. Military Reservation and Atomic Enerç. Comission withdrawal,

d. National Parks and National Monuments, Department of Interior,

3. Lands held by the state of New Mexico,

4. Lands held by private individuals.

Most uranium industry activity is in this checkerboard area and may indirectly affect Indian land even if it is not located on it. The churchrock Mill operated by united Nuclear Corporation, for example, is on private land. But, 
being within the checkerboard area, it is closely sur rounded by Indian land.

The New Mexico Environmental Improvement Board has adopted new regulations for uranium mills. Included is a reouirement that each tailings pile be surcounded by a one-half mile buffer zone. The industry argued against the regulation, citing the checkerboard land ownership pattern. The companies will now be reguired to negotiate with the Indian tribe affected to ensure that the requirement will be met on any Indian land adjacent to the tailings pile. The Navajos have recently reguired a coal company to pay for surface use of land leased for mining. At that time the tribal representative stated that all companies negotiating for surface rights will be charged a price based on the potential value of the use to which the land is put. Thus it is conceivable that the price a uraniua company has to pay for a buffer zone could be based on the value of the yel lowcake produced by the mill.

Almost all of the new uranium projects planned in the state are in remote areas where the few communities are small and isolated. These communities cannot accommodate the rapid growth that would be required to meet the schedules of all of these energy projects Although the state established a community Assistance Council in 1976 to make grants to impacted communities, the state constitution prohibits aid to Indian communities under federal jurisajction. Problems of financing and developing community facilities and housing on Indian lands will impede the achievement of Inaian employment goals which the tribes 
have made a condition for maintaining leases. These problems have no satisfactory solutions at present. There are no existing mechanisms to solve them in the near future.

The lebate within the Navajo Tribe over preservation of cultural valias versus economic development could affect new energy projects, both on and near Indian lands. These concerns are being raised about the proposed New Mexico Generating station at Bisti, the tribe's own proposed generating project west of crownpoint, as well as coal and uranium mining on and near the reservation. Approval by the Tribal council is needed for these projects, but may not be given until these issues are resolved. 
TABLE IV. Uranium Industry Activity on Indian Land 20

\begin{tabular}{|c|c|c|c|c|}
\hline Company & Facility & Lccation & No. Employees & status \\
\hline \multirow[t]{4}{*}{ Anaconda } & $\begin{array}{l}\text { Jackpile-paguate } \\
\text { open pit mine }\end{array}$ & $\begin{array}{l}\text { Laguna Pueblo } \\
\text { near viliage } \\
\text { of Paguate }\end{array}$ & 422 & Operational \\
\hline & $\begin{array}{l}\text { North Jackpile } \\
\text { open pit mine }\end{array}$ & Laguna Pueblo & & $\begin{array}{l}\text { Under development } \\
\text { Overburden being } \\
\text { stripped }\end{array}$ \\
\hline & $\begin{array}{l}\text { P-10 mine } \\
\text { underground }\end{array}$ & Laguna Pueblo & 182 & operational \\
\hline & PW $2 / 3$ & Laguna pueblo & & $\begin{array}{l}\text { New Registration } \\
2 / 17 / 78^{\star}\end{array}$ \\
\hline \multirow[t]{3}{*}{ Conoco } & $\begin{array}{l}\text { Bernabe Under- } \\
\text { ground Mine }\end{array}$ & Laguna Pueblo & & Planning stage \\
\hline & $\begin{array}{l}\text { Crownpoint } \\
\text { Underground Mine }\end{array}$ & $\begin{array}{l}\text { Crownpoint } \\
\text { Navajo Tr ibal }\end{array}$ & & Planning stage \\
\hline & $\begin{array}{l}\text { Borrego Pass } \\
\text { Mine }\end{array}$ & $\begin{array}{l}\text { Navajo unal lot ted } \\
\text { Land }\end{array}$ & & Planning stage \\
\hline Exxon & $\begin{array}{l}400,000 \text { acre } \\
\text { lease Eor } \\
\text { exploration }\end{array}$ & $\begin{array}{l}\text { Navajo } \\
\text { Reservation }\end{array}$ & & Approved 1978 \\
\hline $\begin{array}{l}\text { Gulf Mineral } \\
\text { Resources }\end{array}$ & $\begin{array}{l}\text { Mariano Lake } \\
\text { Mine }\end{array}$ & Navajo Al Iotment & & $\begin{array}{l}\text { New Registration } \\
7 / 27 / 78\end{array}$ \\
\hline Kerr-McGee & $\begin{array}{l}\text { Churchrock \#I } \\
\text { Mine }\end{array}$ & $\begin{array}{l}9 \text { miles NE of } \\
\text { Churchrock } \\
\text { Navajo Land }\end{array}$ & 323 & Operational \\
\hline
\end{tabular}


TABLE IV (cont'd)

\begin{tabular}{|c|c|c|c|c|}
\hline Company & Facil ity & Location & Employees & Status \\
\hline & $\begin{array}{l}\text { Churchrock \#II } \\
\text { and II Mines }\end{array}$ & $\begin{array}{l}9 \text { miles NE of } \\
\text { churchrock } \\
\text { Nav jo Land }\end{array}$ & & Planning stage \\
\hline \multirow[t]{2}{*}{ Phillips } & $\begin{array}{l}\text { Nose Rock \#1 } \\
\text { Underground } \\
\text { Mine }\end{array}$ & $\begin{array}{l}12 \text { miles NE of } \\
\text { Crownpoint } \\
\text { Navajo Tribal Land }\end{array}$ & & $\begin{array}{l}\text { Under development } \\
\text { shaft sinking } \\
\text { Surface Rights - Navajo } \\
\text { MineraI Rights - Santa } \\
\text { Fe RR }\end{array}$ \\
\hline & $\begin{array}{l}\text { Nose Rock \#2 } \\
\text { Underground } \\
\text { Mine }\end{array}$ & $\begin{array}{l}\text { Near Crownpoint } \\
\text { on state Land }\end{array}$ & & Under devel opmemt \\
\hline $\begin{array}{l}\text { Pioneer } \\
\text { Nuclear }\end{array}$ & $\begin{array}{l}\text { Narrow Canyon } \\
\text { Underground } \\
\text { Mine }\end{array}$ & $\begin{array}{l}\text { Near Crownpoint } \\
\text { Navajo Land }\end{array}$ & & Planned \\
\hline \multirow[t]{2}{*}{$\begin{array}{l}\text { United } \\
\text { Nuclear }\end{array}$} & $\begin{array}{l}\text { Northwest } \\
\text { Churchrock } \\
\text { Underground } \\
\text { Mine }\end{array}$ & $\begin{array}{l}\text { NE of Gallup } \\
\text { Najavo Land }\end{array}$ & 531 & $\begin{array}{l}\text { Operational } \\
\text { Navajo Surface Rights } \\
\text { Santa Fe RR Mineral Rights }\end{array}$ \\
\hline & $\begin{array}{l}\text { Old Churchrock } \\
\text { Underground } \\
\text { Mine }\end{array}$ & $\begin{array}{l}16 \text { miles NE } \\
\text { Gallup, Navajo Land }\end{array}$ & & $\begin{array}{l}\text { New Registration } 7 / 14 / 78 \\
\text { Navajo Surface Rights } \\
\text { Santa Fe RR Mineral Rights }\end{array}$ \\
\hline $\begin{array}{l}\text { Western } \\
\text { Nuclear }\end{array}$ & $\begin{array}{l}\text { Ruby \# I Under- } \\
\text { ground Mine }\end{array}$ & $\begin{array}{l}\text { Smith Lake } \\
\text { Navajo Land }\end{array}$ & 67 & $\begin{array}{l}\text { Operational } \\
\text { Surface Rights Navajo } \\
\text { Mineral Rights-Western } \\
\text { Nuclear }\end{array}$ \\
\hline
\end{tabular}




\section{IMPACTS OF TRIBAL INITIATIVES}

The outcome of recent legal cases could affect New Mexico's revenue. Currently, the state levies its taxes on all non-Indian energy companies active in New Mexico regaraless of the location of their operations. It is the ownership of the company, not the ownership of the land, that determines state taxation practice.

As uranium production increases. New Mexico's severance tax is becoming an important revenue source. An increase in the uranium severance tax rate was instituted after lengthy debates in the 1977 New Mexico legislature. The new effective total tax rate is 4.5 percent. The former rate was 1.62 percent. As a result of this increase, fron the period of June 1977 to June $30,197 \mathrm{~B}$, revenue from that one tax brought in $\$ 15,276 ; 765.21$ This amount was greater than had been forecast by state economists when the new rate was originally set. Uranium severance tax revenues still rank behind these of oil and gas. However, the tax rate for oil and gas is higher, and the gap will narrow as uranium production increases and production of the two fossil fuels arops.

Uranium mined on Indian land in the state comprises bout 30 percent of the total production in New Mexico. 22 If the state should lose the authority to tax uranium mined on Indian land, its revenues would certainly suffer. The Crow Tribe's chal lenge of Montana's right to collect severance taxes on coal produced on tribal lands could raise that issue. Should the 
federal appel late court decide the tribe has authority to levy their own severance tax in lieu of the state's, the possibility would have to be taken seriously. In New Mexico, if the Navajo and Laguna tribes decided to pursue this course, New Mexico would lose almost one-third of its uranium severance tax income. These two tribes do not now levy their own severance taxes, so double taxation is not an issue in New Mexico as it is in Montana. This could change, or the tribes could simply oppose the state's authority to levy taxes on uranium from their land.

Another possibility that could affect New Mexico's taxation practices would be increasing Indian ownership in energy operations. Indian ownership in any extractive company might prevent leviance of the state's severance tax on that operation partially or wholly. In a 1977 New Mexico case, the court held that a non-Indian corporation in which the tribe holds an interest cannot be taxed by the state. ${ }^{23}$ The federal court in the Montana case did not rule on whether the tribe could avoid the state tax by being its own mine operator. The NavajoExxon venture falls into this category. The Indian-land severance $t a x$ issue could have important repercussions for New Mexico.

water rights are also an area of controversy between Indians and the State of New Mexico. The N.M. State Engineer has jurisdiction over all water - both surface and grouncwater - within the state. However, Indians, under the winters Doctrine, have rights to ground and surface water under and 
on their lands. Industry has been caught in the middle, being placed in the position of having to decide wintich side to deal with. Non-Indian mineral operators apply to the State Engineer for water permits. The state Engineer will not honot applications for water $r$ ights made to the Indians and the Indians have filed water rights impairment protests against applications made to the state Engineer.

The Navajo Tribe is currently challenging the state's control over groundwater near the reservation. Publis service Company of New Mexico (PNM) has applied to the state Engineer for a water appropriation from the San Juan Basin as a back-up supply source for the New Mexico Generating Station. The Navajo Tribe has protested PNM's application on the grounds that it would interfere with their groundwater supply on the reservation. The decision on this protest could set an important precedent for Indian water rights cases. The winters Doctrine could possibly be used in a court challenge of off-reservation groundwater use interfering with reservation water supplies. 24 The regulation of mine dewatering and the use of discharged mine water has become an important resource use issue in New Mexico. The uranium companies i: the not thwestern corner of the state are discharging large quantities of water that they pump fron their mines in order to gain access to the ore. Legislation has been proposed in both the $33 \mathrm{ra}$ and 34 th Legislatures that would regulate mine water. Under these regulations, the uranium companies would have to show that they were not impairing anyone else's water rights before they 
could dewater. This would shift the burden of proof from other water users to the mining companies. The water would also have to be put to a beneficial use, and the laws are ambiguous on whether or not plaping water to yain access to uranium ore is a beneficial use. On this point, industry argues that mine dewatering does not give them rights to the water, and therefore they should not have to claim a beneficial use for it. However, in anticipation of regulation, the uranium companies have applied Eor rights to over 113,000 acre feet per year. Although no law has been adopted yet, the Legislature has recognized the need to resolve the problem. The affected Indian tribes believe that regulation is needed, but argue that the state should have no jurisdiction; they have therefore opposed the legislation considered. They have also protested over 100,000 acre feet of the water rights applications. In August 1979 the Navajo $\mathrm{Tr}$ ibal Chairman announced a moratorium on all new uranium development on the reservation, citing water contamination and mine dewatering as the bases for the decision.

One of the uses that has been proposed for mine water is power plant cooling. PNM has also negotiated with Phillips Uranium Company to use the water from a Phillips mine for their proposed New Mexico Generating Station. Phillips has prior rights to 2,500 acre feet per annum from the San Juan Basin for the purpose of exploration and mineral resource development. In December 1976, Phillips requested an additional appropriation of 50,000 acre feet per annum from underground mines and deep artesian wells to be diverted and consumed for mineral exploration, shaft 
sinking, project construction, mining, milling, other industrial uses, agricultural use, land reclamation and domestic uses.

In February 1979, the state Engineer advised Phillips that their request had been denied for the reason that the proposed appropriation would "impair existing rights," primarily those of the Navajo Community of Crownpoint. This action did not affect Phillips plans to dewater - it affected only the diversion and consumption of the water. This is because the state has not established jurisoiction over dewatering.

The water table at Crownpoint will drop 1000 feet with in the next 20 years from mine dewatering, according to the $u$. $s$. r ological Survey; impacts of the pumping on ground and surface water levels may continue to be seen for as long as 200 years after pumping stops. 25 In late April 1979, a conference of mining companies, federal agencies and the Navajo Tribe convened to discuss the issue of Crownpoint's water supply. The Navajo position was that the companies should conpensate the tribe for all water used or wasted auring mining operations and for any residual impact of aquifer depletion. The BIA position required assurance of an adequate and permanent water supply of equal quality to the current supply. Five energy companies agreed in principal to investigate supplementing the water supply. Phillips uranium Company agreed to negotiate an agreement to assure an adequate potable water supply to Crownpoint, if all water Iights which provide water for Crownpoint are waivea. 26 In October, 1979, Phillips' request was granted, but 1 imited to 32,250 acre-feet per year. The state 
Engineer also stipulated that if the water table in the Crownpoili area drops 400 feet, the firm's water rights will be terminated prior to the end of the 32.5-year period for which it was granted. Phillips has appealed the decision. 


\section{CONCLUSIONS}

Although nearly one-third of uranium production in New Mexico is taking place on Indian lands, the state has virtually no jurisdiction over the resulting impacts. The state does tax Indian uranium extraction, but impending judicial decisions in other states could ultimately limit its authority. other Indian initiatives to regulate and tax development could strongly impact the industry as well as the state. In turn, state decisions regulating the industry's use of water could adversely impact Indian water resources.

There are many current court cases filed by or against Indian tribes throughout the nation which may set precedents that would change the manner in which the industry may operate. Some cases may restrict the authority of the states to regulate resourcé use or to tax mineral extraction. The Department of Energy should endeavor to determine the implications of these cases for uranium production. This issue paper presents an overview of some of the issues and cases. A comprehensive review and analysis of current litigation related to Indian sovereignty, resource use and control, taxation powers, and environmental jurisdiction should be undertaken. In addition, the DOE should maintain continual awareness of initiatives taken by individual energy resource tribes, CERT, or other Indian organizations in order to assess the influence of Indian self-government on energy production goals. 
AP PENDIX

The ciepartment of Interior has initiated a study of uranium development in the San Juan Basin. Packground information on the study is included here. Part of the study involves researching development activities and impacts on Indian land. The san Juan Basin occupies most of the northwest quadrant cf New Mexicc, and contains almost all of New Mexico's known uranium resources. It contains the New Mexico portion of the Navejo Reservation, Navajo allotted lands, and fee lands, as well as lands belonging to other Indian tribes.

\section{SAN JUAN BASIN REGICNAL URANIUN STUIY (SJPRUS) EACKGROUND} INFORMATION $^{27}$

The SJBRUS, an information gathering effort by the Department of Interior, analyzed the effects of all future uranium development in the San Juan Easin and Grants Mineral Belt. The study has focused on the impacts of uranium develofment activity (exploration, mining, milling, construction and reclamation) on the natural and human environment over a time frame from the present to the turn of the century.

The study addressed the need perceived by Intericr Department to understand the cumulative effects of possible large scale uranium develofment activity for the preparation cf future site specific environmental impact statements. All develogment activity on state, federal, tribal and grivate lands wes considered. 
The study area is defined geologically by the Jurassic outcrop of the Morrison formation. This area encompasses southern Colorado, the southeast corner of Utah, and the northwest guadrant of New Mexico. Within this area, the team focused on the sub-regions that hold the most potential for large scale uranium development.

The study task force was composed of natural and social scientists, frivate consultants and employees of the pureau of Indian Affairs, U. S. Geological Survey, Eureau of vines, Mining Engineering and Safety Administration, Eureau of Land management, Fish and wildife S-rvice, National Park Service, and Eureau of cutdoor Recreation. The Rureau of Indian Affoirs was the lead agency because of its trust responsibilities for Indian lands. 


\section{REFERENCES}

1. Tom Barry, "Why Energy Companies Think Crownpoint Will be the Center of Uranium Boom," Navajo Times, October 12 , 1978.

2. Irvin L. White, et al, Energy from the West: A Progress Report . . Oklahoma Univ. Norman Science and Public Policy Program, June 1977.

3. See James Dick, Mineral Leasing on Indian Lands: Report to the Federal Trade Commission, Federal Trade Commission, washington, DC, Bureau of Competition, October 1975.

4. Tribal Operations office and Real Estate office, Albuquergue Area Bureau of Indian Affairs; New Mexico Bureau of Mines and Mineral Resources; New Mexico Energy Resources Map; Navajo offices of Information and statistics, BIA, Window Rock, 1976.

5. Private communication from a major uranium company.

6. A discussion of federal agency jurisdictions is concained in $M$. Eisenstadt, Legal Infrastructure Related to Uranium Mining, San Juan Basin Regional Uranium Study, Working Paper No. 28, U. S. Department of Interior, 1978.

7. Salt River Project Agricultural Improvement and Power District vs. Navijo Tribe, U.S. District Court, Arizona, sept. 7, 1978 .

8. "Tribes Told New Taxes Could Harm Economy" Albuquergue Journal nid-September, 1978.

9. Dan Liefgreen, "Utah Energy Companies Sue to stop Tribal Tax," Navajo Times, April $12,1979$.

10. "Crow Tribe Seeks Exemption from Montana Coal severance Tax" Western Interstate Energy Board/WrNB Newsletter No. $78-28$, August 4, 1978, p. 10 .

11. Dan Liefgreen, "sulfur Penalty Needs Revision," Navajo Times, January 25, 1979

12. According to $W$. R. Atkins, member of the New Mexico Environmental Improvement Board, Units 1,2 and 3 at Four Corners are achieving a 25-308 reduction through pH balancing of their scrubbers (which were intended for particulate removal when designed). Since Units 4 and 5 (750 Mwe each) have no sulfur removal at present, the overall current removal rate at Four corners is about $a 8$. Sulfur dioxide emissions are about 220 tons per day. 
13. Worcester v. Georgia, 31 U.S. (6 pet.) 515 (18320

United States v. McBratney, 104 U.S. 621 (1881)

Utah and Northern Ry. Co. Y. Fisher, 116 U.S. 28 (1885)

Draper v. United States, 164 U.S. 240 (1896)

Thomas V. Gray, 169 U.S. 264 (1897)

United States v. McGowan, 302 U.S. 535 (1938)

New York ex. rel. Martin v. Ray, 326 U.S. 496 (1946)

Williams v. Lee, 358 U.S. 217 (1959)

organized Viliage of Kake v. Egan, 369 U.S. 60 (1962)

Warren Trading Post Cr. v. Arizona Tax Commission, 880 U.S. $685(1965)$

Kennerly v. District Court of Montana, 400 U.S. 423 (1971) Annis V. Dewey County Bank, 333 F. Supp. 133 (D.S.D. 1971 ) McClanahan V. Arizona State Tax Commission, 411 U.S. 164 (1973 Mescalero Apache Tribe v. Jones, 41 U.S. 145 (1973) Moe v. Confederated Salish and Kootenai Tribes, 425 U. S. 463 (1976)

Bryan v. Itasca County of Minnesota, 426 U.S. Little Horn State Bank v. Stops, 3 Indian L. Rep. h-60 (Mont. 1976)

Fort Mojave Tribe v. San Bernardino County, $543 \mathrm{~F}$. 2nd 1253 (9th Cir. 1976), cert. denied U.S. ct. 1678 (1977)

14. A aiscussion of Indian lands in the uranium producing area is contained in Donald Maynard, "Land Status," San Juan Basin Regional Uranium Study, Working Paper No. $\overline{29}$, U. S. Department of Inter ior, November 24, 1978.

15. Americans for Indian Opportunity, Indians and the Energy Research and Development Administration, 1977, p. 3. The report further states that the BIA is starting to develop inventories of resources on Indian lands.

16. Albuquerque Journal, September 6, 1978.

17. United States, Dept. of Energy, Grand Junction Cffice, Statistical Data of the Uranium Industry, January 1 , 1978, App. B, p.3.

18. Private communication from Robert Meehan, Chief, ore Reserves Branch, Resource Division, Dept. Of Energy, Grand Junction, $\mathrm{co}$

19. Department of Interior, office of the secretary, status Report on Federal and Indian Lands, Northwest New Mexico Area, September $19 \overline{76}$.

20. Private communication from the New Mexico state Mining Inspector and from company representatives.

21. Jeff Radford, "Severance Tax Enrich State", Albuguerque News August 20,1978 . 
22. Private commun ication from an economic analyst in the Tax Research and statistics Office of the New Mexico Department of Taxation and Revenue, $9 / 29 / 78$.

23. Eastern Navajo Industries $v$. Bureau of Revenue, 552 P2d 813 (1977).

24. See Susan Bliss, Overview of Indian water Rights Under the Winters Doctrine, San Juan Basin Regional Uranium study, Working Paper No. 33, Department of Interior, December, 1978.

25. Forest Lyford, Modeled Effects of Uranium-Mine Dewatering on water Resources in Northwestern New Mexico, San $\bar{J}$ uan Basin Regional Ũranium study, Working Paper No. 37 , U.S. Defartment of Interior, January, 1979 ,

26. Casey Watchman, "Crownpoint Residents Discuss Mining Problems," Navajo Times, January 18,1979

27. Excerpted from a SJBRUS news release dated Novamber 15 , 1977. 
Distribution:

U.S. Department of Energy (2)

Albuquerque Operations office

P. O. Box 5400

Albuc jeroue, NM 87185

Attn: D. K. Nowlin

Spec. Proj. Div.

E. R. Williams, Director (25)

Policy Analysis Division/EV 21

U.S. Department of Energy

Forrestal Building, 4G-025

Washington, DC 20585

E. P. Krug (3)

U.S. Department of Energy, RAD/EV 21

Forrestal Building, 4G-025

washirgton, DC 20585

M. Schloss (3)

EV/RAD

U.S. Department of Energy

Germantown, MD 20767

Special Assistant for Indian Affairs Intergovernmentai and Institutiona?

Relations

Forrestal Ruilding

Washington, DC 20585

Jack S. Segal, Director

Environental \& Institutional

Impacts Evaluation Division/PE

U.S. Department of Energy

Forrestal Building, 6F-08!

Washington, DC 20585

Jack Daly, Director

Program Planning \& Analysis Div/IIR

U.S. Department of Bergy

Forrestal Building, 8G-601

washington, DC 20585

Dr. Bruce W. Wachbolz

U.S. Department of Energy

OHER/EV-30

Mail Stop E201

hashington, DC 20545

Jack O'Brien

DOE Denver Office

P. O. Box 26500, Belmar Branch

Lakewood, $\infty 80226$
Robert D. Buchanan

San Juan Basin Regional Uranium Study

U.S. Department of Interior P. O. Box 1590

Albuguerque, NM 87103

Barry helch

Chief, Division of Resource

Develoment \& protection

Albugue roue Area office

Bureau of Indian Af fairs

P. 0. Box 8327

Albuguerque, IM 87101

S. H. Gurbaxani (2)

12413 view Court NE

Albugueroue, $\mathrm{NM} \quad 87112$

L. Barsumian (5)

Oklahoma Legislat ive Co:mcis

State Capi tol

Oklaboma City, CK 73105

1213 W. R. Atkins

1761 A. E. Winblad

4500 E. H. Beckner

4514 M. S. Tierney

4530 R. W. Lynch

4533 B. D. Zak

4533 S. G. Vandevender (10)

8266 E. A. Aas

3141 T. L. Wer: .. (5)

3151 W. L. Garner (3)

for DOE/TIC

(unlimited release)

3154-3 DOE/TIC (25)

R. P. Campeli 